\title{
Manusia Teknologi yang Humanis dan Religius: Perspektif Buddhisme ${ }^{1}$
}

\author{
Oleh Suranto, S. Ag., M. A. ${ }^{2}$
}

\section{Pengantar}

Kemajuan teknologi telah membawa perubahan bagi kehidupan. Perubahan tersebut dapat secara positif maupun negatif. Secara positif, kemajuan teknologi membantu kehidupan manusia untuk meningkatkan kesejahteraan hidup. Melalui teknologi yang canggih, kehidupan manusia dapat melakukan atau mengakses berbagai hal yang dibutuhkan. Sebagai contoh melalui handphone, manusia dapat bertukar informasi secara jelas dan sangat membantu dalam berkomunikasi. Melalui internet informasi apapun dapat diakses. Melalui teknologi canggih dibidang pertanian, hasil pertanian semakin meningkat dan dapat menghasilkan produksi pangan yang melimpah. Terlepas dari hal yang positif ini, tidak luput pula dampak teknologi yang membawa kesuraman kehidupan manusia. Teknologi dapat menjadi bumerang bagi kehidupan manusia. Tidak jarang berita yang disampaikan melalui media massa, televisi, dan lainnya menampilkan dampak negatif dari teknologi. Melalui teknologi yang canggih, industri dapat menghasilkan limbah produksi yang mematikan kehidupan. Teknologi canggih dapat membantu menumbuhkan pikiran serakah manusia untuk mengeksploitasi alam. Alat komunikasi digunakan sebagai sarana perselingkuhan, transaksi narkoba, dan sebagai sarana kejahatan lainnya. Hal di atas menununjukkan dampat dari kemajuan teknologi di era modern ini. Melalui teknologi nuklir, manusia telah membinasakan manusia melalui kemelut peperangan. Oleh karena itu, untuk menyikapi kondisi saat ini perlu dikaji lebih dalam mengenai kehidupan manusia yang kehidupannya tidak terlepas dari perkembangan teknologi.

\footnotetext{
${ }^{1}$ Paper ini disampaikan pada acara "Studium Generale" (Kuliah Umum) dengan tema "Manusia Teknologi yang Humanis dan Religius: Perspektif Agama-agama. Sabtu, 19 November 2011. Di Universitas Kristen Satya Wacana (UKSW), Salatiga.

2 Dosen di Sekolah Tinggi Agama Buddha (STAB) Syailendra dan STAB Negeri Raden Wijaya Wonogiri. Fakus kajiannya pada contemporary issues keagamaan, agama dan bencana, interreligious dialogue, Buddhisme dan lingkungan. Untuk responden dapat menghubungi melalui STAB Syailendra, Jl. Salatiga-Kopeng Km. 12, Deplongan, Wates, Getasan 50774 atau putta_ananda@yahoo.com
} 
Setiap hari, manusia di era modern ini tidak terlepas dari penggunaan teknologi. Meskipun hanya sekedar hanphone, internet, atau televisi. Teknologi tersebut sudah menjadi kebutuhan dan makanan setiap manusia. Para petani sudah tidak terlalu repot mencangkul sawahnya, namun melalui alat traktor, sawah petani dapat digarap dengan waktu yang relatif singkat. Mahasiswa yang awalnya harus bawa buku dan mencatatnya, telah tergantikan dengan laptop dan internet untuk mencari sumber belajar. Orang tua yang ingin menjaga komunikasi dengan anaknya yang di luar kota, dapat melalui internet maupun handphone. Para ibu untuk memasak makanan sudah tidak repot dengan tungku, tapi dengan kompor gas akan lebih cepat dan tinggal klik. Aktifitas-aktifitas di atas sudah menunjukkan bahwa kehidupan manusia saat ini sudah tidak terlepas dari teknologi. Awalnya kemajuan teknologi mungkin akan dianggap luar biasa, namun karena kemajuan teknologi sudah menjamur di kalangan masyarakat, maka akan berubah seolah menjadi kebutuhan. Dengan kata lain, manusia saat ini dapat disebut sebagai manusia teknologi, karena apapun yang dilakukan tidak terlepas dari teknologi. Meskipun dalam kasus tertentu terdapat pula masyarakat yang belum merasakan penggunaan teknologi. Meskipun demikian, lebih tepatnya sudah merasakan dampak dari kemajuan teknologi yang membawa dampak pada kerusakan alam.

Kemajuan teknologi memang bagaikan pisau bermata dua. Di satu sisi, kemajuan teknologi membawa dampak yang positif. Dan di sisi lain, kemajuan teknologi berdampak negatif dan membawa penderitaan dalam kehidupan manusia. Oleh karena itu, perlu pemahaman yang komprehensif dalam menggunakan teknologi, sehingga manusia mampu menggunakan teknologi tepat guna sesuai dengan etika kehidupan. Harapan besarnya, melalui kemajuan teknologi, manusia akan menjadi lebih arif dalam mengembangkan pribadinya sebagai manusia teknologi yang humanis dan religius ${ }^{3}$. Melihat dari aspek humanis, religius, dan aspek etika, Buddhisme sebagai the way of life diharapkan mampu memberikan rambu-rambu dalam memanfaatkan kemajuan teknologi.

\footnotetext{
${ }^{3}$ Sesuai dengan tema dari Studium Generale di UKSW pada tanggal 19 November 2011 yang membahas tentang "Manusia Teknologi yang Humanis dan Religius".
} 
Buddhisme yang selaras dengan ilmu pengetahuan, tentu memiliki perspektif tersendiri dalam memanfaatkan teknologi yang sudah berkembang saat ini. Sejauh ini belum ada pertentangan antara Buddhisme dengan penemuan teknologi baru ${ }^{4}$. Penemuan teknologi sebenarnya tidak terlepas dari hukum sebab musabab yang saling bergantungan. Penemuan teknologi bukan menjadi suatu masalah yang besar bagi kehidupan manusia, karena hal itu sebagai wujud dari usaha manusia untuk mempelajari alam, bukan mengeksploitasi alam. Permasalahan muncul jika dalam penggunaan teknologi tidak tepat pada tujuan utamanya. Pada dasarnya teknologi sebagai suatu sarana yang sifatnya netral ${ }^{5}$. Penemuan teknologi nuklir akan menjadi baik jika penggunaanya tepat untuk meningkatkan kualitas kehidupan manusia. Namun akan menjadi masalah besar jika penggunaan nuklir untuk menghancurkan manusia melalui perang. Maka dari itu, permasalahan dengan teknologi akan mucul jika pikiran manusia tersebut diliputi dengan keserakahan. Yang menjadi masalah bukan pada teknologinya, tetapi pada motovasi manusia dalam menggunakan teknologi tersebut. Oleh karena itu, perlu untuk membahas bagaimana Buddhisme mampu membangun manusia teknologi yang humanis dan religius.

\section{Buddhisme dan Sains}

Perkembangan sains saat ini sebagai bentuk dari perkembangan peradaban manusia. Awalnya sains yang berkembangan dalam masyarakat mendapat tanggapan keras dari kalangan agamawan, terutama berkaitan dengan munculnya teori Galileo Galilei. Ini wujud dari ketidakselarasan dari unsur agama dan ilmu pengetahuaan. Tetapi kondisi tersebut memotovasi manusia pada umumnya untuk mempelajari dan mengkaji alam semesta ini secara mendalam.

Menyikapi kemajuan teknologi dan ilmu pengetahuan, Buddhisme memiliki tanggapan tersendiri. Buddhisme sangat mendorong bagi para ilmuan agar lebih bersemangat dalam melakukan pencarian kesunyataan. Melalui teknologi yang cukup canggih, membuktikan bahwa alam ini tidak hanya terdiri dari satu sistem tata surya. Saat ini telah muncul berbagai penemuan yang menyatakan bahwa

\footnotetext{
${ }_{5}^{4}$ Kirthisinghe, Buddhadasa P., 1999. Buddhism and Science. Delhi, India: Motilal Banarsidas. Hal. 3.

${ }^{5} \mathrm{Ibid}$, hal. 5. Science is neutral; it is man's mind and disposition which ougth to be guided along ecthical lines and that precisely is the fuction of the Buddha teacing
} 
kehidupan ini tidak hanya terjadi di bumi ini dan satu sistem tata surya, melainkan terdapat beberapa sistem tata surya yang dimungkinkan terdapat kehidupan di dalamnya ${ }^{6}$. Catatan penemuan ini juga telah disebutkan pada zaman Buddha. Buddha menyatakan bahwa "sejauh matahari dan bulan berotasi pada garis orbitnya, dan sejauh pancaran matahari dan bulan di angkasa, sejauh itulah luas seribu tata surya. Di dalam seribu tata surya terdapat seribu matahari, seribu bulan, dan kehidupan"7. Keselarasan ini terjadi karena adanya prinsip dasar yang sama antara sains dengan Buddhisme yang mengarahkan manusia untuk tidak begitu saja dengan dogma apapun sebelum membuktikan sendiri. Perbedaanya hanya terdapat pada metode yang digunakan. Pada zaman Buddha pemahaman ini didapatkan dari pencapaian penyempurnaan diri, sedangkan pengetahuan saat ini dibuktikan melalui teknologi yang cukup canggih.

Teknologi yang canggih yang berkembang saat ini sebagai bentuk dan wujud dari kemajuan ilmu pengetahuan. Ilmu pengetahuan dan teknologi membantu manusia untuk membuktikan dan mencari kebenaran. Teknologi yang merupakan alat bantu manusia dalam memahami alam akan menjadi bermanfaat jika dalam penggunaannya tidak bertentangan dengan alam. Meskipun Buddhisme tidak hanya terfokus dengan kamajuan teknologi, tetapi sangat penting untuk memanfaatkan teknologi dengan landasan humanis. Buddhisme memberikan rambu-rambu dalam memanfaatkan tenologi dengan asas cinta kasih dan kasih sayang, sehingga teknologi tidak disalahgunakan dan menyebabkan penderitaan. Dengan kata lain, pemanfaatan ilmu pengetahuan dan teknologi tidak telepas dari motivasi yang dilandasi sikap cinta kasih dan kasih sayang. Paradigma Buddhisme tidak membenarkan jika teknologi yang dipergunakan hanya mengarahkan pada keserakahan dan kebencian. Penggunaan teknologi yang tidak arif justru akan menambah rentetan masalah dan penderitaan kehidupan manusia. Dalam paradigma Buddhisme, ilmu pengetahuan dan teknologi hanya sebagai sarana untuk mencapai tujuan, dan bukan merupakan tujuan itu sendiri.

\footnotetext{
${ }^{6}$ Taniputera, Ivan. 2003. Sains Modern dan Buddhisme. Jakarta: Yayasan Penerbit Karaniya. Hal. 11.

${ }^{7}$ Hare, E. M. (Ed.). 2001. The Book of the Gradual Sayings, vol. III (Anguttara Nikāya). Oxford: The Pali Texts Society. (A.iii.80)
} 


\section{Pendekatan Buddhisme terhadap Kemajuan Sains dan Teknologi}

Diskusi mengenai agama dan ilmu pengetahuan yang ditunjukkan dengan munculnya berbagai kemajuan teknologi masih mewarnai kehidupan di era modern ini. Sepertinya pergulatan agama akan menjadi menarik jika mampu beradaptasi dengan kemajuan teknologi. Kemajuan teknologi yang sudah masuk pada unsurunsur agama, telah menunjukkan bahwa keterpautan antara agama dan teknologi sudah menjadi sebuah interaksi konkrit. Awalnya agama yang menekankan pada masalah kesederhanaan hidup, dan kadang menolak akan kemajuan teknologi, saat ini sudah menjadi kabur. Sebagai contoh, seorang agamawan juga telah memanfaatkan kemajuan teknologi. Buktinya, pemimpin agama tidak luput dari penggunaan telepon seluler, facebook, internet, e-mail, dan berbagai kemajuan teknologi saat ini. Meskipun terdapat pula individu yang masih menolak menggunakan teknologi tersebut. Salah satu contoh, pengalaman saya waktu ke negara gajah putih, Thailand bertemu dengan seorang profesor dan ketika saya mau mencoba untuk membangun jaringan dengan beliau melalui dunia internet, ternyata beliau tidak memiliki alamat email. Beliau juga tidak mempunyai handphone, alamat email dan tidak mau menggunakannya. Tentunya dengan berbagai alasan, mengapa beliau tidak mau menggunakan sarana tersebut dan merupakan salah satu pilihan hidup.

Berbagai pilihan manusia dalam menggunakan teknologi ini mengarahkan pada munculnya berbagai pendekatan terkait agama dan kemajuan ilmu pengetahuan dan teknologi. Salah satu pendekatan yang dapat digunakan untuk memanfaatkan dan menyikapi teknologi, telah dikemukakan oleh John F. Haught ${ }^{8}$. Pendekatan tersebut meliputi pendekatan konflik, kontras, kontak, dan konfirmasi ${ }^{9}$. Pendekatan konflik merupakan pendekatan yang mengatakan bahwa agama sama sekali bertentangan dengan dengan sains, atau dengan kata lain, sains membatalkan agama. Pendekatan ini menunjukkan bahwa agama menolak sains karena sains telah menjatuhkan agama. Pendekatan kontras merupakan pendekatan yang

\footnotetext{
${ }^{8}$ Beliau adalah seorang guru besar Teologi Universitas Goregetown, USA.

${ }^{9}$ Haught, John F.. 1995. Science and Religion:From Conflict to Conversation. New York: Paulist Press. Dapat dilihat juga dalam versi bahas Indonesia di Haught, John F..2004. Perjumpaan Sains dan Agama: Dari Konflik ke Dialog. Bandung: PT. Mizan Pustaka. Hal.xx.
} 
menyatakan bahwa agama dan sains sangat berbeda antara yang satu dengan yang lain sehingga secara logis tidak ada konflik. Pendekatan ini menekankan bahwa agama dan sains sama-sama valid di bidang kajiannya masing-masing. Pendekatan kontak menjelaskan bahwa walaupun agama dan sains berbeda, namun keduanya saling memberikan implikasi-implikasi tertentu. Sains dan agama saling berinteraksi antara yang satu dengan yang lainnya. Oleh karena itu, pedekatan ini lebih menekankan pada interaksi antara agama dan sains, dan bukan saling mengabaikan. Pendekatan lainnya yaitu pendekatan konfirmasi. Pendekatan ini lebih menekankan pada bagaimana agama dapat berperan dalam mendukung petualangan ilmiah. Dengan kata lain, agama dan sains saling membantu mengupayakan cara-cara dan berbagi ide untuk melakukan penyelidikan atau bahkan merestui untuk melakukan penyelidikan.

Pendekatan di atas merupakan salah satu cara untuk memahami hubungan agama dan sains. Jika melihat paradigma Buddhisme bahwa segala sesuatu saling bergantungan dan konsep keterbukaan dalam menyelidiki ajaran Buddha (ehipasiko), menurut saya pendekatan yang dapat menciptakan kedamaian dan keharmonisan kehidupan yaitu pendekatakn kontak dan konfirmasi. Pendekatan ini akan saling memberikan kontribusi. Haught juga menekankan bahwa pendekatan kontak yang dilengkapi dengan pendekatan konfirmasi akan memberikan tanggapan yang bermanfaat dan masuk akal bagi ketegangan yang patut disayangkan yang telah menyebabkan banyak ilmuan tidak menghargai agama dan orang agama yang tidak dapat menikmati temuan-temuan sains ${ }^{10}$. Melalui pendekatan ini akan memunculkan suasana baru dalam kehidupan agama dan sains, sehingga terwujud keselarasan. Seperti halnya pendapat Albert Einstein yang menyatakan bahwa:

"Agama di masa mendatang adalah agama kosmik. Agama tersebut seharusnya melampaui trancend dan menghindari dogma-dogma yang tidak dapat bisa didialogkan. Dengan mencakup bidang alam dan spiritual, agama yang lahir dari pengelaman terhadap segala fenomena alam, spiritual, dan penyatuan yang bermakna. Buddhisme menjawab deskripsi ini. Bila ada agam yang dapat mengatasi kebutuhan modern, agama tersebut adalah Buddhisme"11.

\footnotetext{
${ }^{10}$ Haught, John F..2004. Perjumpaan Sains dan Agama: Dari Konflik ke Dialog. Bandung: PT. Mizan Pustaka. Hal. Xxi.

${ }^{11}$ Taniputera, Ivan. 2003. Sains Modern dan Buddhisme. Jakarta: Yayasan Penerbit Karaniya. Hal. 64.
} 
Jika menyimak pendapat Einstein di atas, Buddhisme memberikan kontribusi yang baik dalam menyediakan ruang bagi perjumpaan agama dan sains. Hal ini telah terbukti dalam usaha memahami ajaran Buddha tidak hanya percaya begitu saja melainkan dengan metode dan penyelidikan yang mendalam. Metode ini tidak jauh berbeda dengan langkah-langkah yang digunakan dalam mengungkap kebenaran ilmiah. Selain itu, tidak mengabsolutkan hasil dari penyelidikan, karena dengan cara dan langkah berbeda tentu akan menghasilkan hal yang berbeda. Oleh karena itu, kemajuan teknologi dan ilmu pengetahuan menjadi sebuah media dan sarana untuk mempelajari hakikat alam dan menambah kebijaksanaan.

\section{Kritik Buddhisme terhadap Penggunaan Teknologi}

Penggunaan teknologi di dalam kehidupan manusia telah menjadi sebuah kebutuhan. Kehidupan saat ini manusia dalam beraktifitas tidak luput dari penggunaan teknologi. Mulai dari alat bantu transportasi sampai alat komunikasi telah manjadi bagian kehidupan manusia dalam menjalankan aktifitas kesehariannya. Saat ini, sangat jarang orang yang tidak memiliki telepon seluler. Handphone sudah marak dalam masyarakat dan menjadi alat komunikasi yang cukup efisien. Melalui sms (short message service), setiap orang dapat berkomunikasi dan saling tukar informasi di manapun berada. Melihat dari manfaat dan kepentingan saat ini, hp sudah menjadi kebutuhan manusia. Berbeda dengan 20 tahun yang lalu, orang memiliki hp sangat jarang dan hanya orang tertentu saja yang memilikinya. Hal ini dipicu pada titik kepentingan dan faktor ekonomi. Meskipun demikian, bukan berarti kemajuan teknologi akan selalu membawa manfaat yang positif, karena dibalik manfaat yang sudah dirasakan juga ada konsekuensi negatif yang mengiringi. Konsekuensi muncul jika tidak dengan bijak dalam memanfaatkan kemajuan teknologi.

Berdasarkan prinsip dasar Buddhisme yang menitikberatkan pada usaha untuk bebas dari penderitaan, terdapat kritik bagi penggunaan teknologi yang tidak bijak. Paradigma Buddhisme tidak memberikan kritikan terhadap kemajuan teknologinya, namun lebih pada penggunaan teknologinya. Secara mendasar teknologi sebagai hal yang netral karena hanya alat bantu. Namun yang lebih 
dikritis pada pengguna yang tidak bijak. Penggunaan teknologi cenderung pada peningkatan keserakahan yang berorientasi pada materialistic oriented. Sebagai contoh saja, dampak dari derasnya arus penjualan mobil dan sepeda motor dapat menimbulkan berbagai polusi udara. Ukuran yang dipakai untuk mengukur kemakmuran terbatas pada jumlah kepemilikan harta benda bukan pada titik mengoptimalkan penggunaan yang sudah dimiliki.

Selain itu, Buddhisme menolak praktik-praktik penyalahgunaan informasi untuk kepentingan pribadi yang merugikan pihak lain. Seperti monopoli informasi, pembajakan karya cipta dan penyebarluasan informasi pribadi (tindak pelanggaran privasi) yang merugikan/merusak nama baik orang lain, serta kegiatan komersial yang memproduksi, menyediakan dan mendistribusikan informasi tanpa memperhatikan dampak negatif bagi masyarakat. Tercermin dari penuhnya media massa baik cetak maupun elektronik dengan pemberitaan dan penyiaran tentang skandal, gaya hidup modern yang boros, hedonisme, kriminalitas, kekerasan dan eksploitasi pornografi.

Pengguna teknologi cenderung masuk dalam arus gensi dan trend. Sebagai contoh satu orang memiliki motor untuk jalan-jalan, motor untuk kerja, motor untuk dipinjamkan. Hal ini menunjukkan tidak memikirkan dampak dari polusi yang dihasilkan dari kendaraan tersebut. Mungkin tidak terasa kalau yang memiliki motor seperti itu hanya segelintir orang, akan tetapi jika setiap orang memiliki pemahaman seperti itu, tentu akan membawa dampak yang cukup signifikan. Pada dasarnya jika menggunakan teknologi secara berlebihan, maka ini yang menjadi kritikan dari Buddhisme. Pertimbangan yang mendasari kritikan ini dilihat dari dampak yang diakibatkan dari penggunaan teknologi yang berlebihan. Oleh karena itu, perlu diimbangi dengan rasa puas, kadang kemajuan teknologi mengarahkan manusia pada keinginan nafsu, karena teknologi akan selalu berkembang terus. Sebagai contoh, orang yang sudah memiliki hp nokia 3315 akan merasa kurang puas jika tidak memiliki blackberry. Hal ini dapat menimbulkan penderitaan baru.

Penggunaan teknologi dapat berimbas pada kecanduan teknologi. Kecanduan teknologi disebabkan karena kemelekatan dengan teknologi dalam benak manusia. Contoh yang saat ini sedang menjadi suatu tren adalah pengunaan teknologi 
internet. Melalui internet, kita dapat memperoleh segala informasi hampir tiada batas, yang positif dan bermanfaat sangat banyak. Tetapi kesempatan untuk terjerumus pada informasi menyesatkan dan merusak juga luar biasa. Bahaya lain dari penggunaan teknologi ini adalah "kecanduan internet". Baru-baru ini hasil penelitian yang dilakukan di Amerika memperkirakan 6\% dari penjelajah dunia maya internet (internet surfer) yang melakukan online sebanyak ukuran standard dapat digolongkan sebagai pecandu internet (Internet Addiction Disorder) ${ }^{12}$. Penderita ini tidak ubahnya penderita kecanduan obat-obatan dan alkohol, sehingga untuk menyembuhkannya memerlukan usaha yang cukup kuat. Sebagai contoh saja, saat ini cukup banyak mahasiswa yang selalu online dengan facebook. Mereka merasa tidak nyaman jika tidak online di facebook, mucul rasa penasaran, tidak tenang karena mengejar informasi yang diupload di facebook. Meskipun ada yang memanfaatkan jaringan sosial ini sebagai kegiatan mengembangkan potensi diri. Mungkin akan lebih banyak lagi efek negatif dari penerapan teknologi ini seiring bertambahnya inovasi-inovasi yang akan muncul kelak, yang belum terbayangkan saat ini.

Penggunaan dan pemanfaatan teknologi jangan dijadikan sebagai alat untuk mengukur si kaya dan si miskin. Namun sebaliknya dengan munculnya kemajuan teknologi justru untuk membantu menyelesaikan masalah sosial dan bukan menciptakan masalah sosial yang baru.

\section{Buddhisme: Manusia Teknologi yang Humanis dan Religius}

Laju perkembangan pemanfaatan teknologi ini tidak dapat dihentikan, namun hanya dapt diarahkan agar mampu menciptakan manusia teknologi yang humanis dan religius. Tidak ada yang tidak dapat berubah dalam kehidupan ini. Tentu ada hal yang harus diubah terutama mind set dalam pemanfaatan teknologi. Buddhisme yang lebih menekankan pada aspek pentingnya menata pikiran, dapat dijadikan sebuah "tuntunan" dalam usaha membangun peradaban manusia teknologi. Paradigma Buddhisme menegaskan bahwa pikiran merupakan pelopor

\footnotetext{
${ }^{12} \mathrm{http} / / /$ sugiminhadi.multiply.com/journal/item/75/AGAMA_BUDDHA_DAN_TEKNOLOGI diakses pada 14 November 2011.
} 
dan pemimpin setiap tindakan ${ }^{13}$. Tidak selalu negatif dari pemanfaatan teknologi ini, dan sangat tergantung dengan kematangan dan tujuan utama dari manusianya dalam menggunakan teknologi. Perlu untuk diketahui bahwa kemajuan dalam perspektif Buddhisme jika semakin sedikit keinginan nafsu maka kondisi seperti itu yang disebut kemajuan besar ${ }^{14}$. Oleh karena itu, perlu mengarahkan diri dalam penggunaan teknologi dalam Buddhisme, sehingga membentuk manusia yang humanis dan religius. Manusia teknologi yang humanis dan religius dapat dipahami sebagai interkoneksi manusia dengan teknologi yang mengedepankan pemanfaatan teknologi pada ranah yang membawa manusia pada peningkatan kualitas diri yang berdasarkan nilai kemanusiaan dan agama.

Dasar moralitas Buddhisme dapat digunakan sebagai pondasi manusia dalam memanfaatkan teknologi. Moralitas Buddhisme yang meliputi menghindari pembunuhan, pencurian, berbuat zina, berbohong, dan minum-minuman keras yang dapat mengurangi lemahnya kesadaran dapat menjadi dasar manusia saat ini. Pelatihan tekad ini dapat menghambat laju penggunaan teknologi yang jika tidak terkontrol dapat merugikan manusia atau orang lain. Kurangnya kontrol dengan teknologi, dapat mengarahkan manusia melakukan pembunuhan, pencurian, perzinahan, kebohongan, dan transaksi narkoba. Melalui bom nuklir telah banyak membunuh kehidupan dan tidak hanya manusia saja. Melalui jaringan sosial dapat menyeret manusia dalam tindakan kriminal, perselingkuhan, dan banyak hal negatif yang dapat dilakukan dengan kemajuan teknologi. Oleh karena itu, tekad atau latihan moralitas Buddhisme dapat dijadikan salah satu pagar dan benteng dari derasnya arus kemajuan teknologi. Moralitas ini menjadi dasar menciptakan keharmonisan kehidupan manusia dan dunia.

Selain itu, menumbuhkan Hiri dan ottapa dalam kehidupan saat ini dalam bergulat dengan teknologi. Hiri merupakan rasa malu untuk berbuat jahat dengan

\footnotetext{
13 Norman, K. R. (Ed.). 2004. The Word of The Doctrine (Dhammapada). Oxford: Pali Texts society. Dhammapada merupakan salah satu kitab suci Agama Buddha yang berisikan kata-kata bijak oleh Buddha yang dikumpulkan berdasarkan pada tema-tema tertentu. Berdasarkan kaidah penulisan kutipan dengan format bahasa Pali, kitab Dhammapada sering disingkat dengan Dhp. Singkatan Dhp menunjukkan bahwa kitab yang digunakan sebagai sumber adalah kitab Dhammapada. Angka di atas menerangkan syair dari kitab tersebut. Syair 1.

${ }_{14}$ Sulak Sivaraksa dalam Kaza, Stephanie dna Kenneth Kraft. 2000. Dharma Rain Souces of Buddhist Evironmentalism: Development as if People Mattered. Boston: Shambhala Publications. Hal. 183.
} 
alasan apapun dan dengan sarana apapu. Sedangkan ottapa merupakan sikap takut akan akibat dari perbuatan jahat. Kedua aspek tersebut dapat membantu membentuk manusia teknologi yang memiliki humanisme dan religiusitas yang matang, meskipun muculnya tawaran kemewahan teknologi. Cara mengarahkan kedua aspek di dunia teknologi dengan cara tidak terlalu melekat dan "haus" dengan teknologi atau dengan kata lain pengendalian diri. Hal ini menjadi dasar sikap dan kematangan mental dalam kehidupan yang serba teknologi.

Sebenarnya jika kita sudah memiliki kematangan dan sikap mental yang mengedepankan cinta kasih dan kasih sayang dapat memanfaatkan teknologi dengan arif. Melalui teknologi digital, ajaran dari para pemimpin agama yang bijak dapat disebarluaskan dan disimpan dengan baik. Mungkin jika tidak ada teknologi membuat kertas, tidak akan ada cetakan kitab suci agama. Kalaupun sudah ditulis didaun dan batu tentu akan lapuk juga dimakan waktu. Melalui digitalisasi, ajaran dan wejangan-wejangan yang bijak masih dapat dirasakan dengan baik sampai saat ini. Teknologi internet juga tidak hanya menawarkan hal yang negatif, namun saat ini nilai kebenaran dan kebijaksanaan dapat diakses melalui internet. Melalui jaringan yang canggih ini akan lebih efektif dalam menggalang dana untuk kemanusiaan. Buktinya, orang Indonesia dapat membantu korban bencana banjir, tsunami, dan gempa yang terjadi di negara lain. Hal ini disebabkan karena kemajuan teknologi yang canggih sehingga informasi yang terjadi daerah atau negara lain langsung dapat kita akses dan melakukan tindakan yang bermanfaat.

Meningkatkan pemahaman bahwa teknologi sebagai sarana untuk mencapai tujuan hidup yang luhur, bukan pada teknologi sebagai tujuan itu sendiri. Pemahaman ini akan membantu kita memaknai teknologi hanya sebagai alat dan saran dalam meningkatkan kualitas diri. Dari kematangan pemahaman ini dapat mendorong manusia untuk mempertimbangkan penggunaan teknologi. Misalnya saja, penambangan yang dilakukan dengan alat yang canggih dengan memperimbangkan unsur alam, sosial masyarakat. Tidak melakukan eksploitasi alam. Dari tindakan ini, teknologi yang diciptakan akan lebih mempertimbangkan pada nilai keselarasan dengan alam dan humanisme. 
Jalan tengah (middle way) sebagai dasar dalam membentuk manusia teknologi yang humanis dan religius. Dengan kata lain, jalan tengah ini menekankan pada bukan anti teknologi dan bukan pada pemujaan teknologi. Manusia memanfaatkan teknologi dengan tidak berlebihan.

\section{Penutup}

Manusia di era ini sudah sulit untuk lepas dari kemajuan teknologi. Manusia hidup dan menjadi bagian dari kemajuan teknologi. Berdasarkan pada paradigma laju kemajuan teknologi yang tidak dapat dihentikan, maka Buddhisme memiliki pemahaman tersendiri mengenai manusia teknologi. Buddhisme tidak menolak mengenai teknologi dan dalam kitab suci juga tidak terdapat larangan untuk bersingungan dengan teknologi. Pada dasarnya Buddhisme dapat menyatu dengan kemajuan teknologi, namun ada hal yang harus dipertimbangkan. Jika terlalu memuja teknologi sebagai tujuan akhir tentu akan membawa dampak negatif. Maka dari itu, prinsip dasar dalam Buddhisme yang menekankan pada aspek cinta kasih dan kasih sayang, dapat mewujudkan manusia teknologi yang humanis dan religius.

Menjadi manusia teknologi yang humanis dan religius tergantung dengan kematangan mental dalam menjalankan moralitas Buddhisme dan menumbuhkan sikap Hiri dan Ottapa. Manusia teknologi hendaknya memiliki tujuan yang benar dalam memanfaatkan teknologi. Tujuan awal dari teknologi adalah sebagai alat atau sarana untuk membantu kehidupan manusia yang dewasa dan sejahtera. Oleh karena itu, melalui prinsip dasar Buddhisme yang mencakup nilai cinta kasih dan kasih sayang, nilai moral, pengendalian diri, dan jalan tengah dalam memanfaatkan teknologi dapat membantu dan membentuk manusia teknologi yang humanis dan religius. Dengan kata lain, manusia mampu beradaptasi dengan kemajuan teknologi tetapi tidak lepas kontrol dan terseret arus teknologi yang membawa pada penderitaan. 